\title{
OBOWIĄZEK WSPÓŁDZIAŁANIA STRON PRZY REALIZACJI ZAMÓWIENIA PUBLICZNEGO
}

\section{UWAGI WPROWADZAJĄCE}

Zamówienie publiczne to odpłatna umowa cywilnoprawna, zawierana pomiędzy zamawiajacym a wykonawca, której przedmiotem jest nabycie przez zamawiającego od wybranego wykonawcy robót budowlanych, dostaw lub usług. Rezultatem tak rozumianego zamówienia publicznego jest stosunek prawny o charakterze obligacyjnym. Samo zamówienie publiczne nie stanowi odrębnego typu umowy, lecz przybiera postać określonej przepisami prawa umowy nazwanej, umowy o charakterze mieszanym lub nienazwanym. Zgodnie z art. 8 ust. 1 Prawa zamówień publicznych ${ }^{1}$ do umów w sprawach zamówień publicznych stosuje się przepisy Kodeksu cywilnego ${ }^{2}$, jeżeli przepisy P.z.p. nie stanowią inaczej. Zastosowanie znajdują tu więc przepisy części ogólnej k.c., w tym przepisy o czynnościach prawnych oraz przepisy prawa zobowiązań.

Nie budzi wątpliwości, że jednym z unormowań, które znajdzie zastosowanie do stosunków prawnych wynikających z zamówień publicznych, sa przepisy art. 354 k.c. określające reguły wykonywania zobowiązań. Z art. 354 k.c. wynika, że wierzyciel nie może w sposób dowolny żądać od dłużnika wykonania zobowiązania. Obowiązki spoczywające na dłużniku muszą mieścić się w ramach określonych treścią zobowiązania jego celem społeczno-gospodarczym oraz zasadami współżycia społecznego. W taki sam sposób, w jaki dłużnik powinien wykonać zobowiązanie, powinien współdziałać z nim wierzyciel. Artykuł 354 k.c. określa więc sposób wykonania zobowiązania, nakładając w tym zakresie obowiązki nie tylko na dłużnika, ale i na wierzyciela.

" Grzegorz Klich, Uniwersytet Ekonomiczny we Wrocławiu, grzegorz.klich@ue.wroc.pl, https://orcid.org/0000-0002-5594-3423.

${ }^{1}$ Ustawa z 11 września 2019 r. - Prawo zamówień publicznych, Dz. U. 2019, poz. 2019 (dalej jako: P.z.p.).

${ }^{2}$ Ustawy z 23 kwietnia 1964 r. - Kodeks cywilny, t.jedn.: Dz. U. 2019, poz. 1145 (dalej jako: k.c.). 
Jeżeli konkretne zobowiązanie ma swoje źródło w umowie, to wówczas pojawia się pytanie, czy strony tej umowy, formułując jej treść, mogą kształtować również zakres obowiązku współdziałania. Z uwagi na to, że wierzyciel zobowiązany jest do współdziałania w wykonaniu zobowiązania przede wszystkim zgodnie z jego treścia, nie ulega wątpliwości, że strony mogą precyzować obowiązek współdziałania przez odpowiednie ukształtowanie treści umowy. Moga także rozszerzać jego zakres o dodatkowe powinności ponad te, które wynikaja z treści art. $354 \S 2$ k.c. Wydaje się, że na tych samych zasadach strony moga ograniczyć te obowiązki lub nawet wyłączyć wierzycielski obowiązek współdziałania, przenosząc cały wysiłek w zakresie starań o wykonanie zobowiązania na dłużnika ${ }^{3}$.

Na obowiązek współdziałania składają się powinności o charakterze zarówno pozytywnym, jak i negatywnym. Pośród najczęściej wskazywanych pozytywnych obowiązków wynikających z zasady współdziałania uwagę zwraca obowiązek odbioru świadczenia, obowiązek informacyjny (udzielenie wyjaśnień czy wskazówek), udostępnienie materiałów i stawienie się na przykład do zdjęcia miary przy umowie o dzieło, wpuszczenie do lokalu w celu dokonania napraw albo udostępnienie placu budowy ${ }^{4}$. Jeżeli chodzi o powinności o charakterze negatywnym, to będą one pełniły podstawową rolę, gdy treść zobowiązania nie wymaga aktywnego współdziałania ze strony wierzyciela przy spełnieniu świadczenia. W takiej sytuacji będzie on miał obowiązek postępowania w sposób lojalny, powstrzymując się od wszystkiego, co mogłoby utrudnić lub uniemożliwić dłużnikowi wykonanie zobowiązania ${ }^{5}$.

Tak sformułowany obowiązek współdziałania znajdował pełne zastosowanie na gruncie przepisów ustawy z 29 stycznia 2004 r. - Prawo zamówień publicznych ${ }^{6}$. Nie budziło to dotychczas wątpliwości doktryny ani orzecznictwa. Pewnym zaskoczeniem jest więc uchwalenie w ramach nowej ustawy Prawo zamówień publicznych art. 431, który stanowi, że „zamawiajacy i wykonawca wybrany w postępowaniu o udzielenie zamówienia obowiązani są współdziałać przy wykonaniu umowy w sprawie zamówienia publicznego, zwanej dalej "umową", w celu należytej realizacji zamówienia"7. Nie jest to historycznie pierwsza sytuacja, w której dla określonego katalogu stosunków cywilnoprawnych ustanawia się szczegółową regulację powinności współdziałania. Wcześniej unormowanie takie obowiązywało bowiem w relacjach między jednostkami gospodarki uspołecznionej. Przedmiotem szczegółowej analizy będzie więc zasadność ustanowienia wskazanej regulacji oraz relacja, w jakiej pozostaje ona z ogólnymi przepisami Kodeksu cywilnego. Pomocne przy tym moga okazać się efekty dociekań doktryny na gruncie nieobowiązujących już przepisów o obrocie uspołecznionym.

\footnotetext{
3 Tak np. Machnikowski (2006): 464-465; odmiennie Klein (1990): 157.

4 Tak np. Czachórski (1994): 209-210; Dąbrowa (1981): 726.

5 Błahuta (1972): 849.

6 T.jedn.: Dz. U. 2019, poz. 1843.

7 Zob. ustawa z 11 września 2019 r. - Prawo zamówień publicznych, Dz. U. 2019, poz. 2019.
} 


\section{OBOWIĄZEK WSPÓŁDZIAŁANIA JEDNOSTEK GOSPODARKI USPOŁECZNIONEJ}

Uchwalając polski Kodeks cywilny, ustawodawca musiał uwzględnić specyfikę funkcjonujacego w kraju ustroju gospodarczego opartego w przeważającej mierze na państwowej działalności gospodarczej. Szereg przepisów nowego Kodeksu regulowało funkcjonowanie obrotu uspołecznionego, czyli stosunków cywilnoprawnych zawiązywanych pomiędzy jednostkami gospodarki uspołecznionej (j.g.u.), które uwzględniać musiały specyfikę tego obrotu, w tym w szczególności swoistą solidarność interesów wierzyciela i dłużnika ${ }^{8}$. Jednym z tych przepisów był, nieobowiązujący już, art. 386 k.c., który formułuje obowiązek współdziałania j.g.u. przy zawieraniu i wykonywaniu umów, określany również mianem „zasady koleżeńskiej współpracy i wzajemnej pomocy"9. Podobnie jak w przypadku art. 354 k.c., już sam normatywny charakter wspomnianego przepisu budził wątpliwości ${ }^{10}$. Doktryna zazwyczaj opowiadała się jednak za interpretacja, zgodnie z którą omawiana regulacja wyrażała obowiązek prawny j.g.u., wobec czego posiadał on charakter normatywny ${ }^{11}$. W szczególności wskazywano, że przepis ten konstrukcyjnie wyraża cywilistyczną koncepcję obowiązku, wskazując podmioty uprawnione i zobowiązane do wypełnienia obowiązku współdziałania ${ }^{12}$.

Określając stosunek zasady wyrażonej w art. 386 k.c. do zasady określonej w art. 354 k.c. wskazywano, że ta pierwsza posiada charakter „wzmożony” oraz że inne jest jej ratio legis. Obowiązek regulowany art. 354 k.c. ma bowiem na celu zabezpieczać uzasadniony interes stron stosunku zobowiąaniowego, natomiast zasada wyrażona w art. 386 k.c. służyła zabezpieczeniu interesu gospodarki narodowej ${ }^{13}$, preferując uwzględnienie interesu ogólnospołecznego przed indywidualnym interesem j.g.u. ${ }^{14}$ Zauważano jednak, że w obu tych przepisach przejawiała się socjalistyczna idea współpracy i wzajemnej pomocy co do zasady obca prawodawstwom „społeczeństw antagonistycznych”15. Co ciekawe, podobna argumentacja przyświecała przyjęciu zasady współpracy stron umowy w przepisach PECL. Jak zauważył Ole Lando, „umowa powinna być uznawana za instrument współpracy, a nie konfrontacji przeciwników, z których każdy dąży do własnej korzyści kosztem drugiego. Powinna ona odzwierciedlać to, co Denis Mazeaud określa mianem esprit collectif. Umowa

8 Trojanek (1971): 50-57. Wskazywano, że jest ona na tyle silna, że konieczne jest, przy użyciu odpowiednich bodźców, działanie w celu zróżnicowania interesów stron. Zob. Klein (1981): 271.

${ }^{9}$ Trojanek (1968): 10.

${ }^{10}$ Wskazywano, że przepisu art. 386 k.c. może być traktowany jako wyłącznie interpretacyjny, stanowiący swoisty manifest czy deklarację programową skierowaną do uczestników obrotu uspołecznionego. Zob. Trojanek (1971): 21.

11 Trojanek (1971): 22 n.; Warkałło (1973): 57.

12 Piasecki (1980): 328.

13 Trojanek (1968-2): 111 n.; Warkałło (1973): 54.

14 Piasecki (1980): 329.

15 Warkałło (1973): 55. 
powinna zabezpieczać solidarność, sprawiedliwość, poleganie na sobie i zaufanie, wartości, których wszyscy, także słabsze podmioty, powinni przestrzegać $^{16}$. W doktrynie wskazuje się wręcz, że zaprezentowane w art. 1:202 PECL podejście do zasady współdziałania stron zobowiązania może stanowić bazę wykształcenia się swoistego „społecznego prawa umów”17.

Wskazywano, że obowiązek współdziałania j.g.u. jest bardziej sprecyzowany oraz szerszy niż obowiązek funkcjonujący w obrocie powszechnym na podstawie wyłacznie art. 354 k.c. Jego znaczenie było większe, gdyż był on podporządkowany bezpośrednio interesom ogólnonarodowym. Zdaniem Zygmunta Nowakowskiego ogólny obowiązek współdziałania dla wykonania zobowiązania w sposób odpowiadający jego treści i celowi społeczno-gospodarczemu w stosunkach pomiędzy j.g.u. nabiera innej formy i treści. W szczególności strony stosunku zobowiązaniowego, wykonując zobowiązanie, muszą mieć na względzie narodowe plany gospodarcze, ekonomiczność produkcji i obrotu oraz zabezpieczenie gospodarki narodowej przed strata$\mathrm{mi}^{18}$. Pojawiały się jednak również opinie, że w odniesieniu do j.g.u. przepisy art. $354 \S 2$ i 386 k.c. określające zasadę współdziałania stron powinny być traktowane łącznie ${ }^{19}$.

W rozważaniach szczegółowych wskazywano, że obowiąek współdziałania stron w dużej mierze uelastycznia prawa i obowiązki stron, zmuszając je do „ukierunkowania i dostosowania współpracy - przy wykonywaniu świadczeń do powstających nowych zdarzeń i stosunków życia gospodarczego. Zmusza to strony - w ramach współpracy - do aktywności i inicjatywy przy wykonywaniu zobowiązań. Zmusza to także strony do powstrzymania się w podejmowaniu działania - przewidzianego umową - jeżeli w nowych okolicznościach może to pociagnać za sobą straty w gospodarce narodowej. Zmusza to nawet czasem strony do zmiany lub rozwiązania już zawartej umowy - co także jest objęte obowiązkiem współdziałania"20. Wskazane dyrektywy prowadziły niekiedy do zmian w zakresie podziału praw i obowiązków, który musiał ustępować pierwszeństwa zasadzie współdziałania. Nie prowadziło to jednak do przekreślenia bezpieczeństwa obrotu, lecz jedynie odsuwało go w określonych warunkach na dalszy plan ${ }^{21}$.

Treść obowiązku współdziałania nie była przez ustawodawcę wyraźnie sprecyzowana. Niekiedy zauważano, że główną rolą tego obowiązku jest uzupełnianie norm prawnych oraz harmonizowanie stosowania prawa i kryteriów ekonomicznych ${ }^{22}$. Jej konkretne elementy odkrywała doktryna oraz orzecznictwo arbitrażowe. Próbę ogólnego określenia treści tego obowiązku podją między innymi Jan Winiarz, który wskazał, że na obowiązek współdziałania przy wykonaniu zobowiązania składa się: ,a) obowiązek wzajemnego informo-

\footnotetext{
${ }^{16}$ Lando (2007): 245-256.

17 Hesselink (2001): 57.

18 Nowakowski (1971): 170-171.

19 Warkałło (1974): 334.

${ }^{20}$ Nowakowski (1971): 170-171.

21 Piasecki (1980): 330.

22 Piasecki (1980): 332.
} 
wania się przez strony o wszelkich faktach i okolicznościach, mających wpływ na wykonanie zobowiązania $[. . .]^{23}$; b) obowiązek podejmowania odpowiednich kroków w celu uchronienia gospodarki narodowej od strat, jakie mogłyby wyniknąc ze sposobu wykonania umowy lub z jej niewykonania; c) obowiązek zmiany lub rozwiązania umowy, jeśli wymaga tego konieczność uwzględnienia zmian w obowiązujacych strony zadaniach planowych, ekonomiczność produkcji i obrotu oraz troska o nienarażenie gospodarki narodowej na straty" ${ }^{24}$. Niekiedy dodatkowo wskazywano, że na treść obowiązu określonego w art. 386 k.c. składa się także obowiązek zawarcia umowy o wykonanie dodatkowych świadczeń (np. robót poprawkowych), którego wykonania można było dochodzić przed komisją arbitrażową ${ }^{25}$.

\section{WSPÓŁDZIAŁANIE STRON UMOWY W SPRAWIE ZAMÓWIENIA PUBLICZNEGO}

Obowiąek współdziałania stron stosunku zobowiązaniowego znajdował zastosowanie do zobowiązań stanowiących rezultat zamówienia publicznego ${ }^{26}$ moca art. 139 dawnego Prawa zamówień publicznych ${ }^{27}$. Ponieważ umowa w sprawie zamówienia publicznego oraz stanowiący jej rezultat stosunek obligacyjny posiadaja charakter cywilnoprawny, zastosowanie do nich przepisów art. 354 k.c. nie budzi wątpliwości. Zgodnie z tym przepisem zakres koniecznego współdziałania wynika przede wszystkim z treści zobowiązania. Dodatkowe obowiązki w tym zakresie mogą jednak również wynikać z zasad współżycia społecznego, ustalonych zwyczajów oraz społeczno-gospodarczego przeznaczenia zobowiązania.

Obowiązek współdziałania stron umowy w sprawie zamówienia publicznego stanowi element treści zamówienia publicznego. Jest to przykład obowiązku stron tego stosunku, który wynika bezpośrednio z przepisów prawa, w szczególności Kodeksu cywilnego, na podstawie art. 354 k.c. w zw. z art. 56 k.c. Z obowiązkiem współdziałania łączy się uprawnienie do oczekiwania, czy nawet w niektórych przypadkach, określonych w przepisach szczególnych, domagania się współdziałania drugiej strony stosunku zobowiązaniowego. Ta

${ }^{23}$ W szczególności chodzić tu będzie o zawiadomienie wierzyciela o tym, że dłużnik nie będzie mógł spełnić świadczenia w terminie. Zob. Klein (1981): 270.

${ }^{24}$ Winiarz (1980): 110. Może tu chodzić także o dookreślenie treści zobowiązania przez następczą czynność prawną np. na podstawie art. 456 k.c. Zob. Klein (1981): 273.

25 Strzępka (1990): 283; Włodyka (1981): 51.

${ }^{26}$ Jak już wskazywano, zgodnie z art. 2 pkt 13 P.z.p. przez pojęcie zamówienia publicznego należy rozumieć umowy odpłatne zawierane między zamawiającym a wykonawca, których przedmiotem są usługi, dostawy lub roboty budowlane.

${ }^{27} \mathrm{~W}$ tym miejscu należy wskazać, że mocą art. 14 dawnego P.z.p. obowiązek współdziałania znajdował również zastosowanie w stosunku do stron postępowania o udzielenie zamówienia rozumianego jako pactum de forma - czyli jako umowa określająca sposób dochodzenia do zawarcia umowy docelowej (porozumienie przetargowe). Szostak (2005): 143. 
„korelatywność” obowiązków i uprawnień stron stosunku prawnego odzwierciedla złożoność treści konkretnych zamówień publicznych ${ }^{28}$.

Należy podkreślić, że na gruncie zamówień publicznych obowiązek ten nabiera szczególnego znaczenia, gdyż stosunek ten wymaga większej stabilizacji i wzmocnienia zasady realnego wykonania zamówienia ${ }^{29}$. Prawidłowe spełnienie świadczenia w ramach tego stosunku uzasadnione jest bowiem interesem publicznym. Udzielanie i wykonywanie zamówień publicznych w większości przypadków wiąże się bowiem bezpośrednio z urzeczywistnianiem interesu publicznego przez realizację zadań publicznych ${ }^{30}$. Zamawiającemu, który zazwyczaj wszczyna postępowanie w sprawie udzielenia zamówienia publicznego, aby w ten sposób, bezpośrednio lub pośrednio, realizować swoje zadania o charakterze publicznym, zależeć więc będzie przede wszystkim na faktycznym spełnieniu świadczenia przez wykonawcę.

Z uwagi na tak ukształtowany społeczno-gospodarczy cel zobowiązania wynikającego z umowy w sprawie zamówienia publicznego obowiazek współdziałania stron występuję tu w o wiele większym natężeniu. Rozwiązanie stosunku prawnego przez jego wypowiedzenie bądź też odstapienie powinno więc stanowić ostateczność, gdyż doprowadzi ono do opóźnienia w realizacji określonych zadań o charakterze publicznym. Na tym tle rysuje się istotne podobieństwo obowiązku współdziałania na gruncie P.z.p. z regulacją art. 386 k.c., ustanawiającego obowiązek współdziałania pomiędzy j.g.u. Należy w tym miejscu zauważyć, że jedna ze stron takiego stosunku często będzie podmiot kwalifikowany na podstawie dawnych przepisów właśnie jako j.g.u. Z uwagi jednak na fakt, że drugą stroną stosunku będzie zazwyczaj prywatny przedsiębiorca, i to nie zawsze krajowy, nie będzie tu występowała wskazana wyżej swoista solidarność interesów wierzyciela i dłużnika w celu zapewnienia należytego funkcjonowania gospodarki narodowej ${ }^{31}$. Realizacja interesu publicznego będzie więc ciążyła wyłącznie na zamawiającym. Trzeba jednak od razu podkreślić, że choć znaczna część zamawiajacych to podmioty wykonujace działalność gospodarczą (np. przedsiębiorstwa państwowe, spółki Skarbu Państwa czy spółki jednostek samorządu terytorialnego), to jednak większość z nich stanowia podmioty realizujące interes publiczny w sposób bezpośredni, zaliczane w szczególności do kategorii jednostek sektora finansów publicznych $^{32}$. Konieczność ochrony interesu publicznego, przejawiającego się w konieczności realnego wykonania zobowiązania, jest więc tutaj nawet bardziej widoczna niż na gruncie dawnego obrotu uspołecznionego. W ramach obrotu uspołecznionego j.g.u. wchodziły bowiem w stosunki obligacyjne $\mathrm{w}$ ramach wykonywanej przez nie działalności gospodarczej z uwagi na konieczność re-

28 Szydło (2014): 167.

29 Szostak (2018): 156.

30 Wieloński (2012): 144.

31 Jak słusznie zauważył Stelmachowski (1969): 153, nie ulega jednak wątpliwości, że w stosunkach cywilnoprawnych interes ogólnospołeczny nie jest głównym celem działania podmiotów nieuspołecznionych.

${ }^{32}$ Zob. art. 9 ustawa z 27 sierpnia 2009 r. o finansach publicznych, t.jedn.: Dz. U. 2013, poz. 855 ze zm. 
alizowania obowiązującego planu gospodarczego. Konieczność współdziałania j.g.u. wynikała więc $\mathrm{z}$ innych przesłanek czy też z inaczej niż współcześnie ujmowanego interesu publicznego ${ }^{33}$.

Mając powyższe różnice na uwadze, można jednak wykorzystać częściowe podobieństwo opisywanych stanów faktycznych, aby wskazać możliwe i celowe sfery współpracy stron stosunku zobowiązaniowego zawiązanego w rezultacie zawarcia umowy w sprawie zamówienia publicznego. Szczególnie przydatne wydaje się tu zestawienie zaprezentowane przez Winiarza ${ }^{34}$. Niewątpliwie w ramach zamówień publicznych funkcjonuje obowiązek wzajemnego informowania się przez strony o wszelkich okolicznościach i faktach mających wpływ na wykonanie zobowiązania. Co więcej, tego typu obowiązek, przynajmniej w stosunku do wykonawcy, wynika zwykle bezpośrednio z treści umowy. W nieco zmienionej wersji można również przenieść na grunt zamówień publicznych drugi, wskazany przez Winiarza, obowiązek nakładający na strony powinność podejmowania odpowiednich kroków w celu zrealizowania zadań publicznych, których realizacja zależy od sposobu wykonania umowy bądź jej niewykonania. Wreszcie, szczególnie interesującą koncepcją wydaje się zastosowanie do zamówień publicznych obowiązku zmiany lub rozwiązania umowy, jeśli wymagałby tego interes publiczny.

Instytucja odstapienia od umowy z tej przyczyny została w sposób wyraźny uregulowana $\mathrm{w}$ art. 145 P.z.p. W odniesieniu natomiast do zmiany umowy P.z.p. w sposób drobiazgowy reguluje sytuacje, w których dokonanie zmian umowy jest zakazane. W pozostałym zakresie dokonanie zmian jest dopuszczalne, ale wymaga złożenia zgodnych oświadczeń woli przez strony. Częstym przypadkiem jest brak zgody zamawiającego na dokonanie zmian w umowie, nawet w dozwolonym przez prawo zakresie. Niekiedy wynikać to będzie ze świadomego zaniżania przez wykonawców oferowanych cen w celu uzyskania zamówienia, a następnie podejmowania przez nich prób wymuszania na zamawiających odpowiedniego zwiększenia należnego im wynagrodzenia. Często stanowić to jednak będzie efekt charakterystycznego dla sektora zamówień publicznych podziału ryzyk pomiędzy strony umowy w sprawie zamówienia publicznego, w ramach którego większość z nich jest przerzucana na wykonawcę. Z uwagi na dominująca pozycję zamawiającego $\mathrm{w}$ kształtowaniu treści umowy wykonawcy z reguły nie mają możliwości skutecznie przeciwstawić się tego typu praktykom. Najczęstszym sposobem minimalizowania negatywnych efektów tego zjawiska jest podnoszenie przez wykonawców cen, tak aby uwzględnić w nich koszty wystapienia różnorakich ryzyk, którymi są oni obarczani. Tego typu działanie nie jest jednak w stanie całkowicie zabezpieczyć interesów wykonawcy. Nieprzewidziane przez strony okoliczności najczęściej bowiem prowadzą do opóźnień w realizacji zamówienia, przed którymi zamawiający zazwyczaj starają się zabezpieczyć przez wprowadzenie do umowy licznych kar umownych. Bezwzględne ich egzekwowanie prowadzi niejednokrotnie do powstawania konfliktów pomiędzy stronami umowy, których

${ }^{33}$ Zob. Stelmachowski (1969): 153.

34 Winiarz (1980): 110. 
rezultatem bywa przerwanie wykonania zobowiązania, a nawet jego rozwiązanie. Często właściwym remedium jest w tej sytuacji dokonanie zmiany umowy $\mathrm{w}$ granicach określonych art. 144 P.z.p., zamawiajacy jednak rzadko wyrażają na to zgodę. W razie zaistnienia tego typu okoliczności obowiązywanie powinności dokonania zmiany umowy mogłoby stać się ważnym instrumentem wspomagajacym rzeczywiste wykonanie zamówienia publicznego, a tym samym realizację interesu publicznego.

Pewne zmiany w zakresie funkcjonowania na gruncie zamówień publicznych obowiązku współdziałania nastapiły wraz z wejściem w życie nowej ustawy Prawo zamówień publicznych. Wskazany akt prawny dokonuje szeregu zmian oraz wprowadza liczne nowe uregulowania nieznane dotychczasowej ustawie. Jednym z nowych przepisów jest art. 431 P.z.p., który stanowi, że „zamawiający i wykonawca wybrany w postępowaniu o udzielenie zamówienia obowiązani są współdziałać przy wykonaniu umowy w sprawie zamówienia publicznego, zwanej dalej "umową", w celu należytej realizacji zamówienia". Jak wskazano w uzasadnieniu projektu: „drugim celem jest wzmocnienie regulacji dotyczących fazy wykonania i ewaluacji umowy w sprawie zamówienia publicznego. Oczywistym jest, że zawarcie umowy nie jest celem w samym $\mathrm{w}$ sobie, celem tym jest należyte wykonanie zamówienia publicznego z poszanowaniem interesów stron umowy. Urzeczywistnieniu tego celu ma służyć wyraźne wyartykułowanie zasady współdziałania zamawiającego i wykonawcy przy wykonaniu umowy, w celu należytej realizacji zamówienia publicznego. [...] Praktyka funkcjonowania rynku zamówień publicznych pokazuje, że strony umowy w wielu przypadkach nie maja świadomości obowiązków, jakie ciążą na nich przy realizacji zamówienia. Wprowadzenie zasady współdziałania zamawiającego z wykonawcą przy realizacji umowy zobliguje ich w wyraźny sposób do współpracy, co pozwoli uzyskać efekt w postaci prawidłowo i rzetelnie wykonanego zamówienia. [...] Przepis wprowadza zasadę współdziałania stron umowy na etapie realizacji zamówienia. Wyraźne uregulowanie przedmiotowej zasady ma przyczynić się do prawidłowej realizacji zamówienia publicznego, przy jednoczesnym poszanowaniu interesów stron umowy"35.

Wprowadzenie tego przepisu do PZP wydaje się wysoce dyskusyjne. Zgodnie bowiem z art. 8 P.z.p.: „do czynności podejmowanych przez zamawiającego, wykonawców oraz uczestników konkursu w postępowaniu o udzielenie zamówienia i konkursie oraz do umów w sprawach zamówień publicznych stosuje się przepisy ustawy z dnia 23 kwietnia 1964 r. - Kodeks cywilny (Dz. U. z 2019 r. poz. 1145), jeżeli przepisy ustawy nie stanowią inaczej”. Zastosowanie na gruncie nowego P.z.p. znajdzie więc również art. 354 k.c., który formułuje przecież dokładnie ten sam obowiązek, który wyrażono w art. 431 P.z.p. Choć bowiem w przepisie tym w sposób wyraźny wyartykułowano społeczno-gospodarczy cel współdziałania stron umowy w sprawie zamówienia publicznego (,w celu należytej realizacji zamówienia”), to jednak nie stanowi on w stosunku do regulacji art. 354 k.c. żadnej nowości. Celem każdego współdziałania stron stosunków zobowiązaniowych jest bowiem należyte wy-

\footnotetext{
${ }^{35}$ Zob. druk Sejmu VIII kadencji nr 3624: $83 \mathrm{n}$.
} 
konanie zobowiąania. Regulacja nowego Prawa zamówień publicznych nie wprowadza również żadnych dodatkowych sankcji za złamanie powinności współdziałania. W dalszym ciagu zastosowanie znajdą tu więc przepisy Kodeksu cywilnego, w tym w szczególności te, które regulują zwłokę wierzyciela.

Za szczególnie chybiony argument uznać należy fragment uzasadnienia, w którym projektodawca wskazuje, że celem wprowadzenia nowego przepisu jest konieczność wyraźnego wyartykułowania tego obowiązku. Obowiązek ten jest już bowiem dostatecznie wyraźnie wyartykułowany w art. 354 k.c., i to od przeszło 50 lat $^{36}$. Tworzenie duplikatów tych samych regulacji w różnych aktach prawnych jest sprzeczne z zasadami prawidłowej legislacji i wprowadza niepotrzebne zamieszanie. Zgodnie bowiem z teorią racjonalnego prawodawcy wprowadzenie nowego uregulowania można uznać za uzasadnione, gdy brak jest wcześniejszej regulacji tego samego zjawiska, chyba że nowy przepis uchyla przepis dotychczas obowiąujący lub wprowadza regulację o charakterze lex specialis $^{37}$. Tak się jednak $\mathrm{w}$ tym przypadku nie stało, a poszukiwanie racjonalnego uzasadnienia wprowadzenia tego przepisu okazuje się bardzo trudne. Przede wszystkim powstaje problem relacji, w jakiej art. 431 P.z.p. ma pozostawać w stosunku do art. 354 k.c.

Szczególnie trudno jest się zgodzić z argumentem, że powtarzanie regulacji z innych ustaw w treści P.z.p. ma ułatwić jego stosowanie, gdyż osoby zajmujące się tą problematyką zazwyczaj sięgają wyłącznie po Prawo zamówień publicznych. Trzeba bowiem w tym miejscu z całym naciskiem podkreślić, że zadaniem ustawodawcy nie jest tworzenie swoistych wyciagów przepisów prawnych na użytek praktyki. Tego typu aktywność powinna być pozostawiona wydawcom literatury prawniczej, którzy rozpowszechniają również teksty aktów prawnych, a w tym i wyciagi różnych aktów prawnych powiązanych funkcjonalnie na użytek praktyki ${ }^{38}$. Nawet gdyby jednak podzielać wskazane wyżej opinie, zasadne jest postawienie pytania o granice takiej „transplantacji”. Dlaczego bowiem konieczne jest przenoszenie do P.z.p. treści zawartych

${ }^{36}$ W Koncepcji Nowego Prawa Zamówień Publicznych (Warszawa 2018), przygotowanej przez Urząd Zamówień Publicznych oraz Ministerstwo Przedsiębiorczości i Technologii, w sposób wyraźny dostrzegalna jest niekonsekwencja autorów w tym zakresie. Na stronie 24 wskazują oni, że wprowadzona zostanie nowa zasada współdziałania zamawiającego i wykonawcy przy wykonaniu umowy, aby na stronie 58 , gdzie zasada ta jest omawiana, wskazać, że przyczyną wprowadzeni tej regulacji jest brak świadomości stron co do istnienia obowiązków w tym zakresie.

${ }^{37}$ Na temat racjonalnego prawodawcy zob. np. Nowak (1973): 166 n.; Tobor (2013): 40 n.; Wronkowska (1990): 120-129. Trzeba jednocześnie zgodzić się z Zirkiem-Sadowskim (1984: 113), który wskazuje, że nie można zawsze wymagać od zasady racjonalnego prawodawcy uniwersalnych i jednoznacznych efektów, gdyż odwoływanie się przez podmiot dokonujący wykładni do tej idei zawsze będzie zachodzić przez pryzmat wyznawanych przez niego wartości i preferencji.

${ }^{38}$ Tego typu praktyka stoi również w sprzeczności z jednym z podstawowych założeń nowego P.z.p., którym jest profesjonalizacja zamówień publicznych. Zgodnie z koncepcją nowego prawa zamówień publicznych, przygotowaną przez Urząd Zamówień Publicznych oraz Ministerstwo Przedsiębiorczości i Technologii, środkiem do osiagnięcia tego celu ma być przede wszystkim wzmocnienie roli Prezesa Urzędu Zamówień Publicznych. Organ ten będzie wspomagał zamawiających w prawidłowym prowadzeniu postępowania, udostępniając potrzebne wzorce dokumentów, budując odpowiednie bazy danych, prowadząc specjalistyczne szkolenia czy nawet tworząc dla zamawiających infolinię. Koncepcja Nowego Prawa Zamówień Publicznych, Warszawa 2018: 21-22. 
w art. 354 k.c., z pominięciem innych - być może nawet istotniejszych z punktu widzenia zamówień publicznych - regulacji cywilnoprawnych? Regulacje podmiotowości prawnej, zdolności do czynności prawnych, wykładni oświadczeń woli czy też skutków czynności prawnych także przecież znajdują zastosowanie na gruncie regulacji P.z.p., nikt jednak, powołując się na potrzeby praktyki, do tej ustawy ich nie przenosi.

Rozwiązaniem, które do pewnego stopnia łagodziłoby negatywne skutki tej niepotrzebnej aktywności prawodawcy, mogłoby być skorzystanie $\mathrm{z}$ formy tradycyjnych przepisów odsyłajacych. Przyjmując więc założenie, że pojedyncze odesłanie w art. 8 nowego P.z.p. do przepisów k.c. nie zawsze jest dla praktyków zajmujących się zamówieniami publicznymi wystarczająco czytelne, można dla większej transparentności tej regulacji częściej stosować przepisy odsyłajace. Przykładowo, art. 431 P.z.p. mógłby otrzymać następujace brzmienie: „do współdziałania stron przy wykonaniu zobowiązania z umowy w sprawie zamówienia publicznego stosuje się art. 354 k.c.”. Tego typu rozwiązanie nie wprowadzałoby zamieszania w ramach regulacji Prawa zamówień publicznych i uniknięto by wątpliwości co do treści oraz wzajemnej relacji wskazanych przepisów. Alternatywnym rozwiązaniem jest nadanie art. 431 P.z.p. charakteru przepisu szczególnego w stosunku do regulacji art. 354 k.c., odpowiednio wzbogacając jego treść, w szczególności wskazując na konkretne obowiązki w zakresie współdziałania stron.

Z uwagi jednak na obecne brzmienie art. 431 nowego P.z.p. należy przychylić się do opinii wyrażonej niegdyś przez Alfreda Kleina w odniesieniu do art. 386 k.c. Na przełomie lat osiemdziesiątych i dziewięćdziesiątych, kiedy wdrażane były szerokie reformy gospodarcze, autor ten zauważył, że dalsze obowiązywanie art. 386 k.c. nie jest potrzebne. Jak wskazał Klein: „odpada potrzeba formułowania osobno ogólnej powinności współdziałania stron umowy na użytek stosunków między j.g.u., gdy ich stosunki prawne w dobie reformy gospodarczej powinny być poddane tej samej regulacji co pozostałe stosunki w obrocie profesjonalnym. Zreszta, formuła art. $354 \S 2$ k.c. zupełnie wystarcza dla nałożenia na wierzycieli ogólnej powinności współdziałania z dłużnikiem"39.

\section{PODSUMOWANIE}

Obowiązek współdziałania stron stosunków zobowiązaniowych należy traktować jako element szerszej zasady poszanowania zasad słuszności w prawie prywatnym. Podstawowe znaczenie we wprowadzaniu zasad słuszności do prawa prywatnego odgrywaja klauzule generalne. Chodzi tu szczególnie o klauzule zasad współżycia społecznego, społeczno-gospodarczego przeznaczenia prawa, dobrych obyczajów oraz zasad uczciwości obrotu, spośród któ-

${ }^{39}$ Klein (1990): 160. 
rych dwie pierwsze zostały wykorzystane w treści art. 354 k.c. ${ }^{40}$ Jak zauważa Marek Safjan: „prawo cywilne kieruje się sprawiedliwością typu wyrównawczego (komutatywna), nakierowane jest na ochronę praw podmiotowych i interesu prawnego uczestników obrotu, przywrócenie naruszonej równowagi $\mathrm{w}$ relacjach między podmiotami. W pewnym uproszczeniu mówiąc, realizuje koncepcję słuszności akcentująca równoważenie interesów w perspektywie relacji indywidualnych, a nie globalnych relacji społecznych, co jest domeną prawa publicznego [...]. Idee sprawiedliwości wyrównawczej realizowanej przez mechanizmy prawa prywatnego nie moga być osiagnięte wyłącznie poprzez precyzyjną i wyczerpujacca regulację prawna, musi ona bowiem pozostawiać konieczny »luz decyzyjny« dla organów stosujących prawo, zapewniać elastyczność rozwiąań, które mogą być w najbardziej adekwatny sposób dostosowane do okoliczności konkretnych sytuacji prawnych"41. Taki luz decyzyjny zapewniają niewątpliwie regulacje posługujące się klauzulami słusznościowymi, w tym w szczególności klauzulą zasad współżycia społecznego. Wydaje się, że unormowanie art. 354 k.c. stanowi właśnie przykład prywatnoprawnego mechanizmu realizującego idee sprawiedliwości wyrównawczej.

Współcześnie zasada współdziałania stron stosunków zobowiązaniowych spotyka się z coraz większym zainteresowaniem na gruncie europejskich porządków prawnych. Wiąże się to z odejściem od koncepcji pozytywistycznych, właściwych prawodawstwom XIX oraz pierwszej połowy XX w. Zyskujace na popularności idee solidarystyczne głoszące, że umowa powinna być uznawana za instrument współpracy, a nie konfrontacji, faktycznie prowadzić mogą do swoistego „uspołecznienia” niektórych elementów prawa umów. Przemawia za tym choćby eksponowanie zasady współdziałania na poziomie międzynarodowym, szczególnie na gruncie zasad PECL. Wydaje się, że idea ta, oparta przecież na fundamencie dialogu i współpracy, nie powinna być uznawana za „ciało obce” także w polskim porządku prawnym. Nie można bowiem zapominać, że ustrój gospodarczy naszego państwa opiera się na zasadach społecznej gospodarki rynkowej.

Na gruncie Prawa zamówień publicznych, podobnie jak dawniej w ramach obrotu uspołecznionego, wydźwięk tego przepisu wydaje się jednak nieco inny. Regulacja ta nie dąży bowiem wyłącznie do równoważenia interesów w perspektywie relacji indywidualnych (zamawiajacy-wykonawca), ale ma również na celu realizowanie określonych interesów publicznych. Pozostawanie na styku oddziaływania klasycznych regulacji słusznościowych, właściwych prawu cywilnemu, oraz unormowań publicznoprawnych dążacych do ochrony interesu publicznego stwarza więc dla regulacji art. 354 k.c. potencjalnie o wiele szersze pole działania. Interes publiczny, przejawiający się w dążeniu do realnego wykonania zobowiązania powstałego z zamówienia publicznego, wymagać bowiem może o wiele szerszego zakresu współdziałania. Ze względu na tę szczególną cechę stosunków obligacyjnych, stanowiących efekt zawarcia umowy w sprawie zamówienia publicznego, dopuszczalne wydaje się więc

40 Safjan (2007): 299-300; Stelmachowski (1998): 282 n.

41 Safjan (2007): 296 n. Zob. również Stelmachowski (1998): 109 n. 
szersze interpretowanie omawianego obowiązku na gruncie regulacji Prawa zamówień publicznych, tak aby w możliwie największym stopniu sprzyjać rzeczywistemu wykonaniu zobowiązania. Pomocne dla określenia poszczególnych powinności mieszczących się w tym zakresie mogą być efekty dociekań doktryny oraz orzecznictwa poczynione przy interpretacji nieobowiązującego już art. 386 k.c.

Jednakże obecne brzmienie przepisu art. 431 P.z.p. nie stanowi, w ocenie autora, dobrego rozwiąania. Przepis ten nie wnosi bowiem do regulacji zamówień publicznych żadnej nowej treści. Stanowi on jedynie przeniesienie na grunt regulacji P.z.p. zasady, która i tak znajdowałaby tam zastosowanie na mocy art. 354 k.c. w zw. z art. 8 P.z.p. Postulowanym rozwiązaniem jest więc co najmniej zmiana treści art. 431 P.z.p. bądź to przez przekształcenie go w przepis odsyłający do art. 354 k.c., bądź też utworzenie z niego regulacji szczególnej w stosunku do tego artykułu, w czytelny sposób rozdzielającej ich zakresy zastosowania.

Błahuta, F. (1972). Komentarz do art. 354 k.c., [w:] J. Ignatowicz (red.), Kodeks cywilny. Komentarz 2. Księga trzecia - zobowiązania. Warszawa: 847-849.

Czachórski, W. (1994). Zobowiązania. Zarys wykładu. Warszawa

Dąbrowa, J. (1981). Wykonanie zobowiązań, [w:] Z. Radwański (red.), System prawa cywilnego. Tom 3, cz. 1: Prawo zobowiązań - część ogólna. Wrocław: 714-758.

Hesselink, M. (2001). The principles of the European contract law: some choices made by the Lando Comission, [w:] M. Hesselink, G. de Vires (eds.) Principles of European Contract Law. The Hague: 5-95.

Klein, A. (1981). Wykonanie umowy i odpowiedzialność, [w:] L. Bar (red.), Instytucje prawne w gospodarce narodowej. Wrocław: 270-273.

Klein, A. (1990). Skutki prawne braku współdziałania wierzyciela z dłużnikiem, [w:] J. Frąckowiak, E. Gniewek, A. Śmieja (red.), Prace prawnicze. Prawo 186. Wrocław: 144-160.

Lando, O. (2007). The structure and legal values of the Common Frame of Reference (CFR). European Review of Contract Law 3: 245-256.

Machnikowski, P. (2006). Struktura zobowiązania, [w:] E. Łętowska (red.), System prawa prywatnego. Tom 5: Prawo zobowiązań - część ogólna. Warszawa: 108-171.

Nowak, L. (1973). Interpretacja prawnicza. Studium z metodologii prawoznawstwa. Warszawa.

Nowakowski, Z. (1971). Wykonywanie zobowiazań, [w:] S. Buczkowski, Z. Nowakowski, Prawo obrotu uspołecznionego. Warszawa: 169-172.

Safjan, M. (2007). Zasady prawa prywatnego, [w:] M. Safjan (red.), System prawa prywatnego. Tom 1: Prawo cywilne - część ogólna. Warszawa: 262-311.

Stelmachowski, A. (1969). Wstęp do teorii prawa cywilnego. Warszawa.

Stelmachowski, A. (1998). Zarys teorii prawa cywilnego. Warszawa.

Strzępka, J. (1990). Rozkład ryzyka przy wadliwym współdziałaniu zamawiającego w umowach inwestycyjnych, [w:] S. Wójcik (red.), Prace cywilistyczne. Warszawa: 272-289.

Szostak, R. (2005). Przetarg nieograniczony na zamówienia publiczne - zagadnienia konstrukcyjne. Kraków.

Szostak, R. (2018). Umowy o zamówienia publiczne w zarysie. Warszawa.

Szydło, M. (2014). Prawna koncepcja zamówienia publicznego. Warszawa.

Tobor, Z. (2013). W poszukiwaniu intencji prawodawcy. Warszawa.

Trojanek, J. (1968a). Obowiązek przestrzegania zasad współżycia społecznego w stosunkach obrotu uspołecznionego. Ruch Prawniczy, Ekonomiczny i Socjologiczny 30(4): 1-12.

Trojanek, J. (1968b). Zasada współpracy i wzajemnej pomocy w stosunkach obrotu uspołecznionego (art. 386 k.c.). Poznań. 
Trojanek, J. (1971). Obowiązek współdziałania jednostek gospodarki uspołecznionej przy zawieraniu i wykonywaniu umów. Warszawa.

Warkałło, W. (1973). Ogólne zasady wykonywania zobowiązań. Studia Prawnicze 37: 43-57.

Warkałło, W. (1974). Klauzule wyłączające odpowiedzialność za szkodę a ubezpieczenie odpowiedzialności cywilnej. Ruch Prawniczy Ekonomiczny i Socjologiczny 36(3): 325-340.

Wieloński, M. (2012). Interes publiczny w zamówieniach publicznych. Warszawa.

Winiarz, J. (1980). Wykonanie zobowiązań wynikających z umów między jednostkami gospodarki uspołecznionej, [w:] Z. Gordon, K. Kwaśniewski, J. Łopuski, J. Winiarz, Prawo obrotu gospodarczego. Warszawa: 109-122.

Włodyka, S. (1981). Prawo gospodarcze. Zarys systemu - część ogólna. Tom 1. Warszawa.

Wronkowska, S. (1990). Prawodawca racjonalny jako wzór dla prawodawcy faktycznego, [w:] S. Wronkowska, M. Zieliński (red.), Szkice z teorii prawa i szczegółowych nauk prawnych. Poznań: 117-134.

Zirk-Sadowski, M. (1984). Rozumienie ocen w języku prawnym. Łódź.

\section{THE DUTY TO CO-OPERATE DURING THE PERFORMANCE OF PUBLIC PROCUREMENT}

\section{Summary}

The purpose of the article is to draw the reader's attention to the existing duty for parties to a relationship of obligation to co-operate at the performance phase of such an obligation. This duty is applicable to all types of obligations. However, it is most often analysed in connection with obligations arising from contracts. In this context, it is interesting how the duty to co-operate applies to obligations which are the effects of public procurement contracts. The article examines this problem in great detail. Reference is made to both the previously applicable law as well as the new Polish public procurement regulation.

Keywords: duty to cooperate; public procurement; obligations 
